\title{
Incidental giant adrenal lymphangioma presenting as a non-functional cystic mass
}

\author{
Mehmet Tolga Kafadar ${ }^{1}$ (D) Ekrem Özyuvalı² (D), Abdullayev Mirsaleh Miryaguboğlu³ (D), Tuğba Çaviş ${ }^{4}$ (D), Aydın İnan ${ }^{5}$ (D) \\ ${ }^{1}$ Clinic of General Surgery, Mehmet Akif Inan Training and Research Hospital, Şanlıurfa, Turkey \\ ${ }^{2}$ Clinic of Urology, Mehmet Akif Inan Training and Research Hospital, Şanlıurfa, Turkey \\ ${ }^{3}$ Department of General Surgery, Azerbaijan Medicine University, Baku, Azerbaijan \\ ${ }^{4}$ Clinic of Radiology, Atatürk Training and Research Hospital, Ankara, Turkey \\ ${ }^{5}$ Clinic of General Surgery, Ankara Umut Hospital, Ankara, Turkey
}

\begin{abstract}
Adrenal masses can be encountered with many different clinical manifestations and a diverse spectrum of etiologies in clinical practice. Recent advances in imaging and laboratory studies as well as their increasingly widespread use and easy accessibility have currently made it possible to diagnose a greater number of surrenal masses than ever. The basic approach principles vary for incidentally detected masses, benign/malignant masses, and hormonoactive masses. Lymphangiomas are benign congenital malformations of lymphatic channels that primarily affect the neck and head region. They typically affect children younger than 2 years of age, they are uncommon in adults and they rarely involve surrenal glands. In this paper, we aimed to present a woman with a hormonally inactive right giant adrenal mass showing recent rapid growth, which was diagnosed to be a lymphangioma in an atypical localization in histopathological examination. The patient was operated with right adrenalectomy and total mass excision via laparoscopic lateral transperitoneal approach.
\end{abstract}

Keywords: Adrenal masses, laparoscopic surgery, lymphangioma

Cite this article as: Kafadar MT, Özyuvalı E, Miryaguboğlu AM, Çaviş T, Inan A. Incidental giant adrenal lymphangioma presenting as a non-functional cystic mass. Turk J Surg 2021; 37 (3): 299-302

\section{Corresponding Author}

Mehmet Tolga Kafadar

E-mail: drtolgakafadar@hotmail.com

Received: 06.12.2016

Accepted: 12.06.2017

Available Online Date: 28.09.202

( ) Copyright 2021 by Turkish Surgical Society Available online at www.turkjsurg.com

DOI: $10.47717 /$ turkjsurg.2021.3785

\section{INTRODUCTION}

When deciding to proceed with surgery for adrenal masses, their size, hormonal activity, imaging signs suggestive of malignancy, and growth rate at serial examinations should be taken into account. There is no consensus for a size threshold beyond which surgical intervention becomes necessary. While some authors have advocated that surgical mass excision should be limited to masses larger than $6 \mathrm{~cm}$ based on the knowledge that masses smaller than $6 \mathrm{~cm}$ are associated with a negligible risk of malignancy, some others have recommended surgery for masses larger than $3 \mathrm{~cm}$ and some others for masses larger than $4 \mathrm{~cm}$ (1). Herein, it was aimed to present a woman with a nonfunctional giant right adrenal mass that turned out to be a lymphangioma, a tumor that is uncommonly considered in the differential diagnosis in this localization.

\section{CASE REPORT}

A 39-year-old female had been under follow-up at an outside center for a right adrenal mass for 8 years. She presented to our urology department after her mass had grown rapidly and caused abdominal pain over the last 6 months. Her past history was not notable for any disorder. On physical examination, she had tenderness in her right lateral and right upper quadrants. Biochemical tests and hemogram parameters were in normal range. A preoperative endocrinologial evaluation including a 24-hour urine collection for vanylmandelic acid, epinephrine, metanephrine, norepinephrine, normetanephrine, dopamine; plasma renin and angiotensin levels; and $1 \mathrm{gr}$ dexamethasone suppression test were all normal. An abdominal computed tomography (CT) revealed a well-bordered mass lesion with a size of $86 \times 70 \mathrm{~mm}$ and millimetric calcifications in the right adrenal gland; the mass was primarily considered to be a surrenal cyst shifting surrounding structures. Magnetic resonance imaging (MRI) examination demonstrated a cystic lesion measuring 9x7 $\mathrm{cm}$ in the right adrenal gland, which appeared hypointense on axial T1 A and axial 



Figure 1. A cystic lesion in the adrenal gland; which appears hypointense on axial T1A (a), axial fat suppression T1A images (b) and hyperintense on fat suppression T2A images (c).


Figure 2. Histological view of the lymphangioma of the right adrenal gland; multiloculated cyst within the adrenal gland (a), cells positively stained with CD31 and D2-40 on the wall of the multilocular cystic lesion which contains areas of focal dystrophic calcification and is divided by fine septae (b). (H\&E:200x).

fat suppression T1A images and hyperintense on axial fat suppression T2A images (Figure 1a,b,c). A surgical intervention was scheduled on the basis of recent rapid growth, signs of compression, and patient's desire to become pregnant. The patient underwent laparoscopic lateral transperitoneal right adrenalectomy in which the mass and the right adrenal gland were excised. The patient had no problem during the postoperative period and was discharged 2 days later. Immunohistochemical examination showed CD31-and D2-40-positive cells on the wall of the multilocular cystic mass, and the lesion was identified as a lymphangioma (Figure 2a,b). Informed consent was obtained from patient who participated in this case.

\section{DISCUSSION}

Despite the general knowledge that adrenal mass lesions are typically benign and do not release any hormones, each mass should also be evaluated and differential diagnosis should be done for hypersecretory syndromes or tumor development (2). The management of hormonally inactive adrenal masses is primarily based on lesion size. As inactive masses smaller than $3 \mathrm{~cm}$ are typically of benign character, their conservative follow-up is usually recommended. Inactive masses between 3-5 $\mathrm{cm}$ in size can be conservatively managed when they appear homogenous in radiological imaging studies. However, surgery should be considered whenever radiological studies indicate growth. Hormonally active masses should be surgically excised irrespective of their size (3).

CT and MRI are the most appropriate imaging modalities for differentiating adenoma, carcinoma, and pheochromacytoma from one another. These imaging modalities are also very beneficial for determining surgical candidacy from an anatomicopathological standpoint (4).

Following the introduction of laparoscopic surgery for adrenal adenomas, it has been rapidly incorporated into clinical practice, and studies comparing laparoscopic and open surgeries have been published. Laparoscopic surgery has the main advantages of short hospital stay, reduced postoperative pain, rapid re- 
covery, and better cosmetic outlook. Since its first introduction, laparoscopic approach has been the technique of choice for the treatment of benign functional and non-functional adrenal mass lesions (5). Recently, indications of laparoscopic interventions have been extended to larger adrenal masses and adrenal metastatic lesions. Different laparoscopic techniques have been defined for the resection of adrenal masses, including lateral transabdominal, lateral retroperitoneal, anterior transabdominal, and posterior retroperitoneal approaches. Among these, lateral transperitoneal approach is widely used for adrenal mass lesions (6).

Adrenal cysts are rare, typically asymptomatic lesions that are usually detected postmortem, they are clinically important since they can be confused with malignant lesions. Symptomatic lesions manifest with the tirad of pain, palpable mass, and inferior displacement of the kidney. These lesions have 4 major groups, which are the parasitic, endothelial, epithelial and pseudocytsic types. Despite affecting every age from newborn to old age, they are most commonly observed in middle-aged women (7).

Lymphangiomas are benign congenital malformations of lymphatic channels that primarily affect the neck and head regions. Approximately $50 \%$ of these lesions are diagnosed at the time of birth and $90 \%$ during the first 2 years of life. They are quite rare in adulthood. Ninety-five percent of lymphangiomas are located in the neck and axillary region while the rest develop in mediastinum, mesentery, omentum, retroperitoneum, and bones. Their diagnosis is made by physical examination, history taking and imaging studies (8).

Cystic lymphangiomas are composed of sequestered lymphatic sacs. Although the histogenesis of lymphanigomas is still debated, some researchers assume that they are acquired lesions secondary to the obstruction of chylous vessels by inflammatory, traumatic and degenerative conditions. In contrast, cystic lymphangiomas have been reported to occur congenitally, as a result of the proliferation of embryonic lymph sac remnants. It is the general opinion that lymphangiomas are composed of sequestered lymphatic sacs that fail to establish a link with main lymphatic channels (9).

Despite having a benign character, cystic lymphangiomas may lead to compression of adjacent organs and obstruction and they may also invade surrounding structures. No spontaneous regression is expected in adulthood lymphangiomas. Total surgical excision is necessary for their treatment. Incision, drainage and repeat aspirations have been used as primary therapies, although recurrences and infections have proved ineffective $(9,10)$. As the mass lesion of our patient had recently grown rap- idly and compressed surrounding structures, surgical excision was decided despite the lack of any suspicion for a malignancy.

\section{CONCLUSION}

Albeit rare, lymphangiomas should be considered in the differential diagnosis of adrenal masses in adult patients. Definite diagnosis is made after the surgical removal by histological and immunohistochemical examinations. As they are deeply located in the retroperitoneal area, lateral transperitoneal laparoscopic surgery can be readily used for their treatment owing to its advantages such as shorter hospital stay, early return to daily life and superior cosmetic outcomes.

Peer-review: Externally peer-reviewed.

Author Contributions: Concept - M.T.K., E.Ö.; Design - M.T.K., A.M.M., A.I.; Supervision - M.T.K., E.Ö., A.M.M., T.Ç.; Materials - M.T.K., E.Ö., T.Ç.; Data Collection and/or Processing - M.T.K., T.Ç., A.I.; Analysis and/or Interpretation - M.T.K., E.Ö., A.M.M.; Literature Search - M.T.K., A.M.M.; Writing Manuscript - M.T.K.

Conflict of Interest: No conflict of interest was declared by the authors.

Financial Disclosure: The authors declared that this study has received no financial support.

\section{REFERENCES}

1. SworczakK, Babniska A, Stanek A, et al. Clinical and histopathological evaluation of the adrenal incidentaloma. Neoplasma 2001; 48:221-6. [CrossRef]

2. Erdem H, Çetinkünar S, Kuyucu F, Erçil H, Görür M, Sözen S. Surgical approach in adrenal incidentalomas: Report of thirteen cases and review of the literature. Ulus Cerrahi Derg 2015. [CrossRef]

3. Moreira SG Jr, Pow-Sang JM. Evaluation and management of adrenal masses. Cancer Control 2002; 9:326-34. [CrossRef]

4. Khanna S, Priya R, Bhartiya SK, Basu S, Shukla VK. Adrenal tumors: An experience of 10 years in a single surgical unit. Indian J Cancer 2015; 52:475-8. [CrossRef]

5. McKinlay R, Mastrangelo MJ Jr, Park AE. Laparoscopic adrenalectomy: indications and technique. Curr Surg 2003; 60: 145-9. [CrossRef]

6. Kim KH, Lee Jl, Bae JM. Significant growth of adrenal lymphangioma: A case report and review of the literature. Int I Surg Case Rep 2015; 17: 48-50. [CrossRef]

7. Ates LE, Kapran Y, Erbil Y, Barbaros U, Dizdaroglu F. Cystic lymphangioma of the right adrenal gland. Pathol Oncol Res 2005; 11: 242-4. [CrossRef]

8. Pui MH, Li ZP, Chen W, Chen JH. Lymphangioma: Imaging diagnosis. Australas Radiol 1997; 41: 324-8. [CrossRef]

9. Joliat GR, Melloul E, Djafarrian R. Cystic lymphangioma of the adrenal gland: report of a case and review of the literature. World J Surg Oncol 2015; 13: 58. [CrossRef]

10. Nuzzo G, Lemmo G, Trischitta MM, Boldrini G, Giovannini I. Retroperitoneal cystic lymphangioma. J Surg Oncol 1996; 61:234-7. [CrossRef] 


\section{OLGU SUNUMU-ÖZET \\ Turk J Surg 2021; 37 (3): 299-302}

\section{Non-fonksiyonel kistik kitle şeklinde presente olan insidental dev sürrenal lenfanjiom}

Mehmet Tolga Kafadar ${ }^{1}$, Ekrem Özyuvalı ${ }^{2}$, Abdullayev Mirsaleh Miryaguboğlư ${ }^{3}$, Tuğba Çavişş ${ }^{4}$ Aydın İnan ${ }^{5}$

1 Mehmet Akif Inan Eğitim ve Araştırma Hastanesi, Genel Cerrahi Kliniği, Şanlıurfa, Türkiye

${ }^{2}$ Mehmet Akif Inan Eğitim ve Araştırma Hastanesi, Ürololoji Kliniği, Şanlıurfa, Türkiye

${ }^{3}$ Azerbaycan Tıp Üniversitesi, Genel Cerrahi Anabilim Dalı, Bakü, Azerbaycan

${ }^{4}$ Atatürk Eğitim ve Araştırma Hastanesi, Radyoloji Kliniği, Ankara, Türkiye

${ }^{5}$ Ankara Umut Hastanesi, Genel Cerrahi Kliniği, Ankara, Türkiye

\section{ÖZET}

Sürrenal kitleler klinikte çok farklı etiyolojiler ve farklı klinik bulgularla karşımıza çıkabilmektedir. Görüntüleme ve laboratuar tekniklerinde sağlanan gelişmeler ve bunların giderek daha yaygın ve kolay kullanılması, daha fazla sürrenal kütlenin tanımlanabilmesini sağlamaktadır. İnsidental kütlelere, benign/malign kütlelere ve hormonoaktif kütlelere yaklaşım birbirlerinden farklıdır. Lenfanjiyomlar esasen baş ve boyun bölgesini etkileyen lenfatik kanalların benign konjenital malformasyonlarıdır. Genellikle iki yaş altı çocuklarda görülen lenfanjiomların, erişkin hastada ve özellikle sürrenalde görülmesi çok beklenmez. Bu makalede, takipte son zamanlarda hızlı büyüme tespit edilen, hormonal olarak inaktif sağ dev surrenal kütlesi olan ve histopatolojik incelemede alışılmadık lokalizasyonuyla lenfanjiom tanısı alan bir erişkin kadın olgu sunuldu. Olguya laparoskopik lateral transperitoneal yaklaşımla sağ sürrenalektomi ile birlikte total kütle eksizyonu yapıldı.

Anahtar Kelimeler: Adrenal kütle, laparoskopik cerrahi, lenfanjiom

Doi: $10.47717 /$ turkjsurg.2021.3785 